\title{
The Incarnation of the Word: Andrea Della Robbia's Annunciation and Adoration Altarpieces at La Verna
}

\author{
Stephanie R. Miller
}

check for

updates

Citation: Miller, Stephanie R. 2021. The Incarnation of the Word: Andrea Della Robbia's Annunciation and Adoration Altarpieces at La Verna. Religions 12: 624. https://doi.org/ $10.3390 /$ rel12080624

Academic Editor: Hilaire Kallendorf

Received: 4 June 2021

Accepted: 9 July 2021

Published: 10 August 2021

Publisher's Note: MDPI stays neutral with regard to jurisdictional claims in published maps and institutional affiliations.

Copyright: (C) 2021 by the author. Licensee MDPI, Basel, Switzerland. This article is an open access article distributed under the terms and conditions of the Creative Commons Attribution (CC BY) license (https:/ / creativecommons.org/licenses/by/ $4.0 /)$.
Department of Visual Arts, Coastal Carolina University, Conway, SC 29528, USA; smiller@coastal.edu

\begin{abstract}
On the mountainous crest of the Apennines are several buildings comprising the monastic site of La Verna where St. Francis received his stigmata in 1224. Described in 1493 as another Jerusalem in the West, the monastery's Chiesa Maggiore, Santa Maria degli Angeli, and the Chapel of the Stigmata house its most prominent images, Andrea della Robbia's five altarpieces (c. 1476-c. 1493). This essay explores the beholder's experiences before Andrea's earliest two altarpieces at the Observant Franciscan monastery, the Annunciation and Adoration. The history and function of this monastery are considered in light of the themes of these altarpieces and their theological significance. Of relevance are the inscriptions on the altarpieces, which rather than simply identifying the accompanying images, propose interesting interpretations and influences for the altarpieces and which suggest interactive involvement between beholder and the altarpieces in the monastic spaces. Taken together, these works reveal a sensitivity to the specific needs of the Franciscan audience, context, and location and an awareness of Renaissance devotional practices.
\end{abstract}

Keywords: Andrea della Robbia; Franciscan; La Verna; altarpiece; Incarnation; inscriptions

\section{Introduction}

Situated in the peak of the Apennine Mountains is the remote Franciscan monastery of La Verna, described in 1493 by Fra Alexandro de Riciis as another Jerusalem in the West, a site of profound devotion for the intrepid pilgrim (Chiappini 1927, p. 331; Ritsema van Eck 2017, pp. 271-72). The isolated environment was ideally suited to hermetic life and is best known as the location of St. Francis' meditations and ultimately where he received his stigmata in 1224 . Set within a stunning landscape, the monastic buildings are unassuming and relatively unadorned, reflecting the Franciscan ideals of simplicity, humility, and poverty. The public spaces of the monastic compound include three principal buildings of devotion: Santa Maria degli Angeli, the Chiesa Maggiore, and the Chapel of the Stigmata, the location of Francis' stigmatization (Figures 1 and 2). Within these buildings are five altarpieces that were commissioned from Andrea della Robbia between c. 1476 to c. 1493 . The Annunciation (c. 1476), Adoration of the Child (1479), and Ascension of Christ (c. 1493) are in the Chiesa Maggiore. The Ascension of Christ was originally the high altarpiece for the Chiesa Maggiore but was moved in 1601 to a side chapel in the church's choir. The Madonna della Cintola (1486) is in the small church near the monastery's entrance, S. Maria degli Angeli, and the Crucifixion altarpiece (1481) is in the Chapel of the Stigmata. Two more enameled terra cotta altarpieces by Andrea's son were later added to S. Maria degli Angeli, and the Madonna del Rifugio attributed to Andrea della Robbia, now in the Chiesa Maggiore, was moved here in 1874 (it was not originally intended for the monastery). This is not to imply there are no other altarpieces at La Verna but rather that the robbiane altarpieces are distinct among them due to their shared medium of enameled terra cotta. 


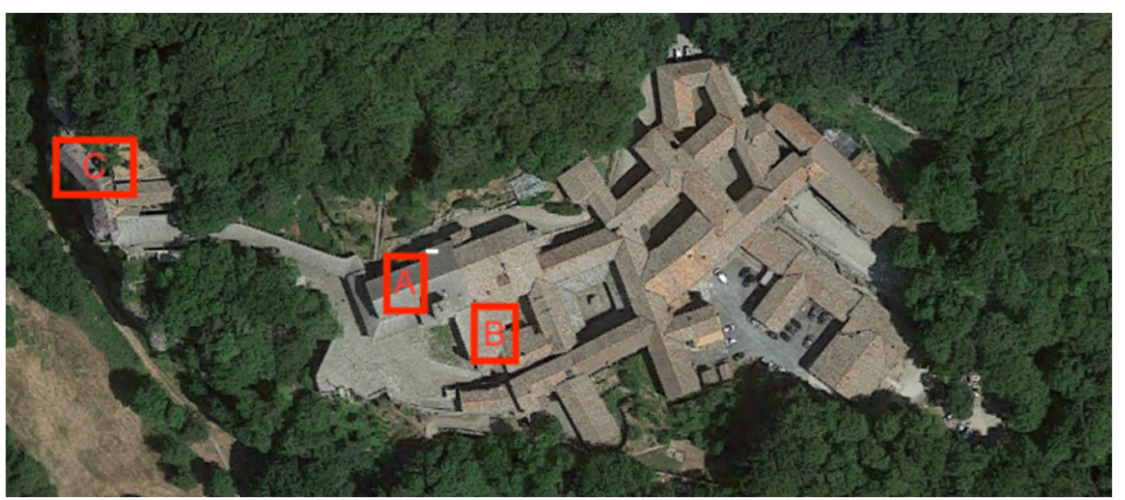

Figure 1. Aerial view of La Verna monastery. (A) Chiesa Maggiore; (B) Santa Maria degli Angeli; (C) Chapel of the Stigmata.

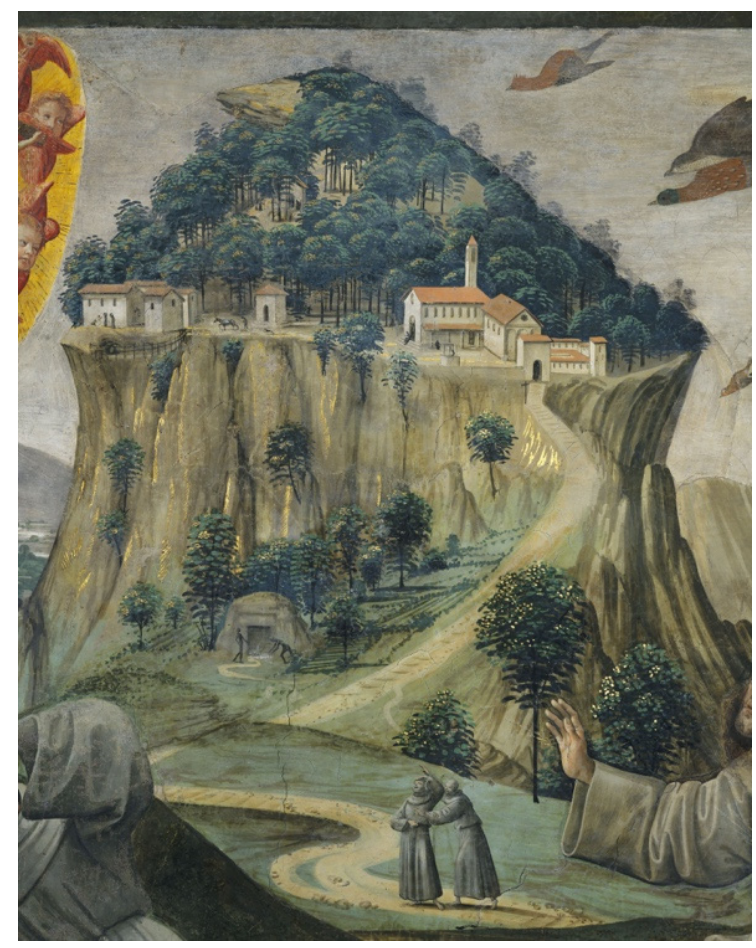

Figure 2. Domenicino Ghirlandaio, detail of La Verna from Sassetti Chapel, Santa Trinita, Florence. Fresco. 1483-1486 (photo source: Scala/Art Resource, NY).

In recent decades, renewed scholarly attention has been given to the prolific Della Robbia family, its workshop and vast body of work, and that of its followers. These studies range from attribution questions to multifaceted investigations into the enameled terracotta medium and to a first-ever North American exhibition dedicated to Della Robbia, which has generated even more scholarly interest in a host of related areas (Gentilini 1992a, 1998; Cambareri 2016; Kupiec 2016; Hykin 2017; Boyd 2020; Sarnecka 2020). This study considers the fifteenth-century context and interpretation of two altarpieces attributed to Andrea della Robbia for the Chiesa Maggiore at La Verna, the Annunciation and the Adoration.

\section{Discussion of Inquiry}

Fra de Riciis' text and other early modern visitor accounts to the sanctuary focus on the sites where miracles and visions were said to have occurred, including the Chapel of the Stigmata and S. Maria degli Angeli where a vision of the Virgin appeared to Francis (Chiappini 1927; Conigliello 1999; Moroni 1999). Subsequent scholarship has also often concentrated on the Chapel of the Stigmata and its Crucifixion altarpiece (Miller 2010; 
Boucher 2001, pp. 14-16; Ritsema van Eck 2017, chp. 6). Of other recent scholarship on the La Verna altarpieces, questions of material, process, and patronage have been explored (Muzzi 1998; Domestici 1991; Baldini 2012, 2014; Tripodi 2014; Lumini and Bordini 2019). Nevertheless, traditional art historical questions of context and interpretation persist, especially for the sculpted altarpieces in the Chiesa Maggiore.

Andrea della Robbia's enameled terra cotta sculpted altarpieces were among the few images at the Observant Franciscan monastery in the fifteenth century (Baldini 2012; Miller 2003). Unlike Conventual Franciscans who emphasized St. Francis' life and his miracles, the Observant order strictly followed the Rule of St. Francis, his vow of poverty, and love of the Virgin; Andrea's La Verna altarpieces likewise reflect the Saint's devotion to the life of Christ and to the Virgin. As the location of St. Francis's stigmatization, it is not surprising that De Riciis' 1493 chronicle focused on the Chapel of the Stigmata, the heart of the monastery, with Andrea's Crucifixion altarpiece by providing a verbal picture of how a worshipper experienced this chapel (Figures 3 and 4). The Crucifixion with Saints Francis and Jerome accentuated the anguish of the Virgin with an inscription along the base (Jeremiah's Lamentations [I:12]: $\mathrm{O}$ all ye that pass by the way attend and see if there be any sorrow like my sorrow; O VOS OMNES QVI TRA[N]SITIS P[ER] VIAM ATTE[N] DITE ET VIDETE SI EST DOLOR SCIVT DOLOR MEVS). With these words, the Virgin refers to Jeremiah's loss at the fall of Jerusalem in the Old Testament as a way to describe her own sorrow at the loss of her crucified son (Wallis 1973, p. 14). Significant to the present inquiry is Fra de Riciis' description of the beholder's interactive experience before the Crucifixion in this chapel. He records the worshipper's specific recitation and kneeling devotional pose, which mirrors that of Saints Francis and Jerome in the altarpiece (Chiappini 1927, p. 333; Miller 2010). Although De Riciis mentioned the Annunciation altarpiece, he, unfortunately, provided no comparable account for how pilgrims engaged with Andrea's two earlier altarpieces in La Verna's Chiesa Maggiore (Chiappini 1927, p. 335). However, his own chronicle and other relevant Franciscan literature, such as the Meditations on the Life of Christ, suggest that worshippers actively engaged with devotional imagery and objects to inspire a religious experience. Therefore, De Riciis' description of the pilgrim's absorbed, "somaesthetic" experience before the Crucifixion encourages a consideration of how a beholder would have interacted with other images and inscriptions at La Verna. Allie Terry-Fritsch defined somaesthetics as an awareness for how the body is attuned to sensory, aesthetic experiences and argued that, as a critical framework, the "viewer is a powerful tool" in the discovery of meaning (Terry-Fritsch 2020, chp. 1). Such an approach can rely on how the viewer makes meaning through touch or smell, for instance (Classen 2012; Sarnecka 2020; Karmon 2016; Quiviger 2010). This essay, however, considers, in part, how the fifteenth-century lay person or pilgrim relied on visual, spatial, and textual cues (spoken and written) to interpret the altarpieces in the Chiesa Maggiore. The Annunciation and Adoration altarpieces are also interpreted through a Franciscan lens and contextualized by the monastery as a way to examine how the altarpieces inspired devotional experiences at the monastery.

Like the Crucifixion altarpiece, the viewer of the Annunciation and Adoration altarpieces (Figures 5 and 6) was encouraged to empathize with the Virgin Mary, who was a model of prayer and piety and in this way a devotional guide for the worshipper visiting the monastery (Reinburg 2012, pp. 214, 218). While the Crucifixion altarpiece in the most sacred space of the monastery inspired a physical, interactive response before it, the Annunciation and Adoration altarpieces when read together implied a similar, albeit more modest interaction with devotees arriving at La Verna who would construct meaning through their presence by visually connecting the two altarpieces. Location is a meaningful factor in appreciating the altarpieces and the objectives of their viewers. Pilgrims embarked on a journey to this New Jerusalem because of the site's significance. Conditioned by various devotional practices, rituals, and texts, including domestic worship, pilgrims and lay worshippers brought such familiar practices with them to La Verna, prepared to engage with the environment and its images. In this way, the beholder can be appreciated as 
a "critical technology" that augments the meaning of the altarpieces (Terry-Fritsch 2020, chp. 1).

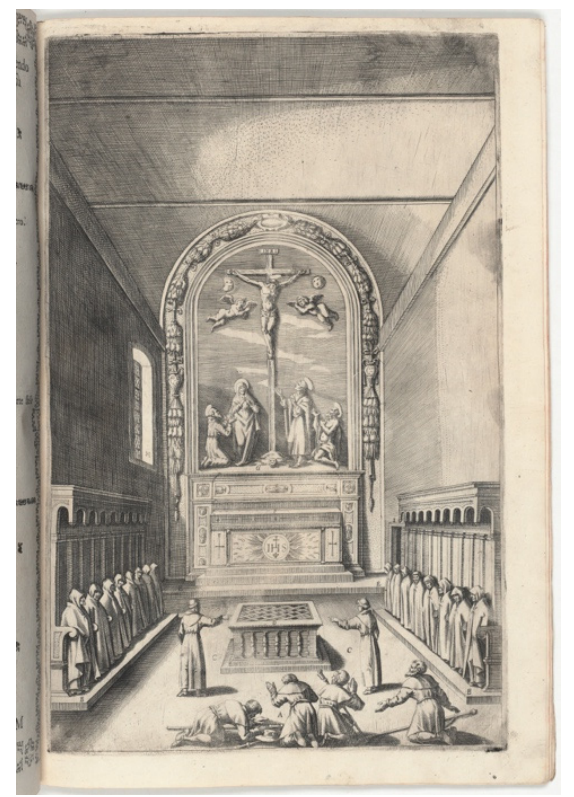

Figure 3. Jacopo Ligozzi, Chapel of the Stigmata, plate M, engraving from Lino Moroni's descrizione del Sacro Monte della Vernia, 1612 (photo source: Courtesy National Gallery of Art, Washington).

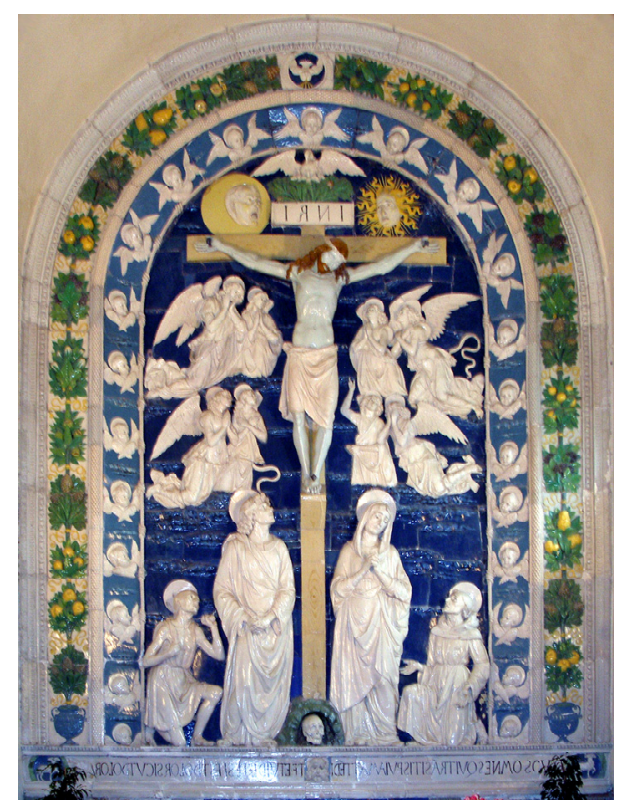

Figure 4. Andrea della Robbia, Crucifixion, enamel terra cotta, Chapel of the Stigmata (photo source: Tetraktys, Public domain, via Wikimedia Commons).

The "phenomenon" of the New Jerusalem pilgrimage experience likely dates to 1491 and the sacro monte of Varallo, but in many respects, as argued by Ritsema van Eck, La Verna is the "primordial sacro monte" due to the site's physical connections to Francis's stigmatization and the belief that the mountain of La Verna split at the moment of Christ's crucifixion (Ritsema van Eck 2017, pp. 247-49). As access to the Holy Land itself became increasingly difficult for the Christian west in the fifteenth century, local alternatives, such as the sacro monte (sacred mountain) were developed to simulate such a pilgrimage, but to a "new" Jerusalem in the West. Throughout the sixteenth century, New Jerusalems, 
such as that at Varallo, became elaborate architectural and sculptural programs to provide the experience of visiting the Holy Land but without the foreign travel. Anna Giorgi noted that at the time of Andrea's first La Verna altarpiece, the Annunciation (c. 1476), La Verna was on its way to becoming the "natural" sacro monte and Jerusalem of the West as described by De Riciis in 1493 (Giorgi 2012, pp. 56-57). Furthermore, she mentions Domenicino Ghirlandaio's depiction of La Verna in the Sassetti Chapel in Florence's S. Trinità (1483-1486, Figure 2) as fairly characterizing the simplicity of the monastery before later architectural developments, such as the sixteenth-century additions of a guesthouse and a corridor leading to the Chapel of the Stigmata (Giorgi 2012, pp. 56-57). By the time of Ghirlandaio's fresco, most of Andrea's La Verna altarpieces would have been installed.

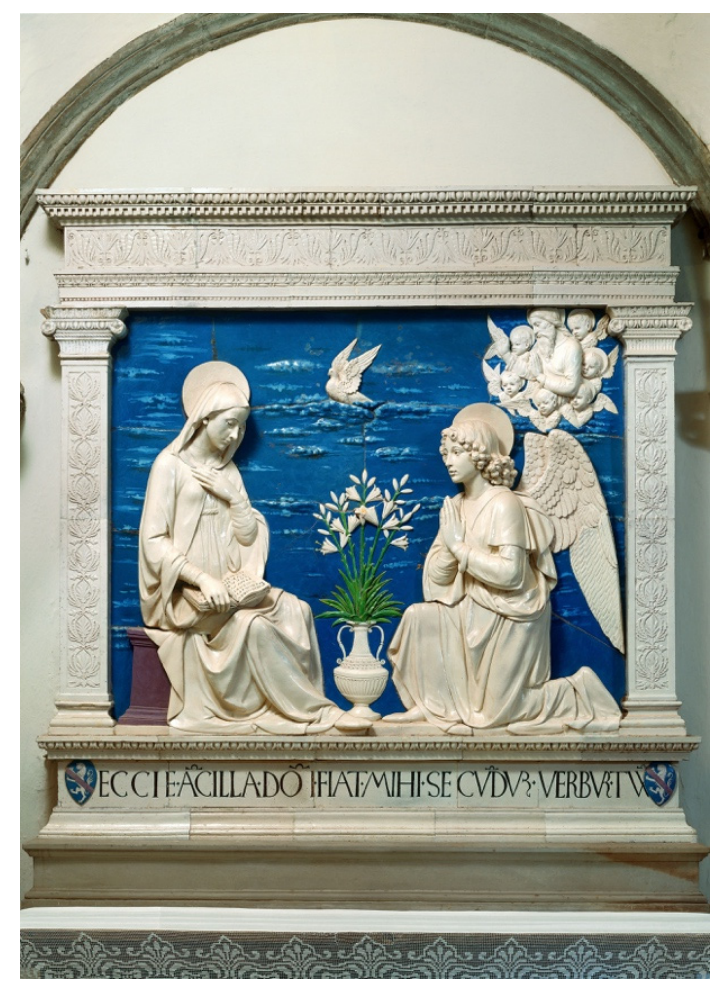

Figure 5. Andrea della Robbia, Annunciation, enamel terra cotta, Chiesa Maggiore, La Verna (photo source: Scala / Art Resource, NY).

Traditional art historical questions of interpretation and intention have rarely been posed to Andrea della Robbia's numerous autograph works. This is true even of Andrea's most frequently praised achievements, his La Verna altarpieces. A consideration of the Annunciation and Adoration reveals how Andrea and his work in enameled terra cotta complemented Observant Franciscan theology and how the compositions and inscriptions of these altarpieces in particular demonstrated Andrea's artistic sensitivity and awareness of the devotional needs of visitors to the monastery's public spaces and to the Chiesa Maggiore, in particular (Baldini 2009, p. 417). The Virgin and her role in the Annunciation and Incarnation are uniquely emphasized in these altarpieces with their inscriptions to facilitate a refined understanding of the Incarnation as encouraged by Franciscan theology and devotional practices. The possible recitation of the Angelus prayer, with passages analogous to the inscriptions on Andrea della Robbia's Annunciation and Adoration altarpieces in the Chiesa Maggiore, is discussed as an example of how the works inspired prayer. 


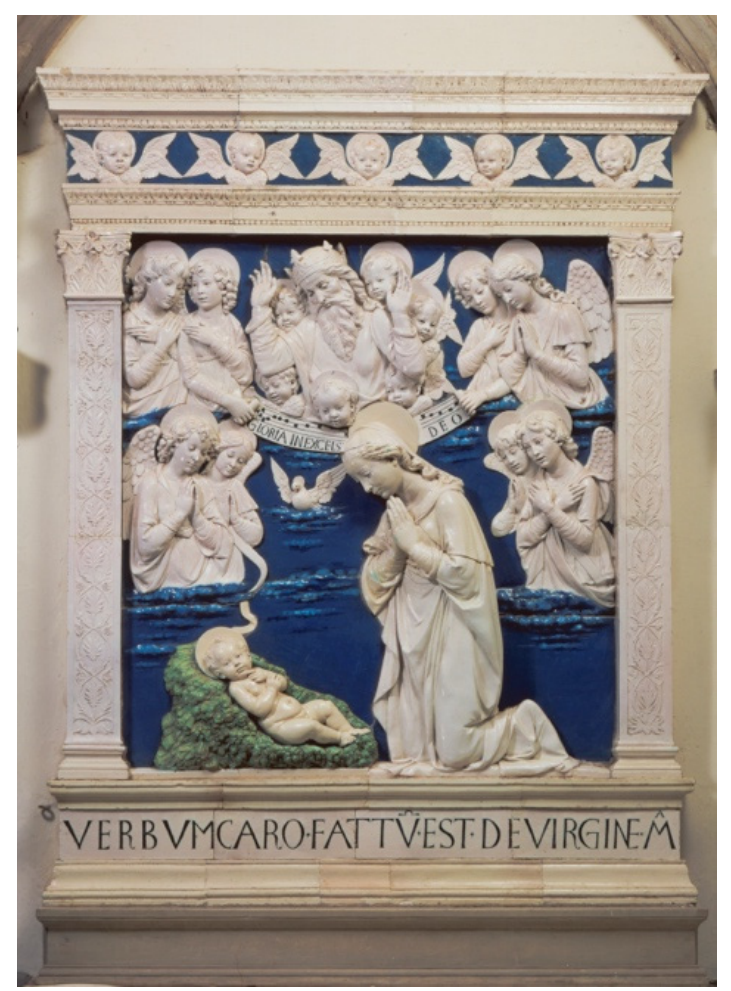

Figure 6. Andrea della Robbia, Adoration, enamel terra cotta, Chiesa Maggiore, La Verna (photo source: Scala/Art Resource, NY).

\section{La Verna and the Chiesa Maggiore in the Fifteenth Century}

The La Verna monastery lacks a unified architectural plan, and its style and irregular appearance reflect the simplicity and poverty dear to Observant Franciscans. ${ }^{1}$ The Chiesa Maggiore is expectedly plain (Figures 7-9), and as the largest and last church built on the mountain, it was intended to accommodate the growing number of pilgrims to La Verna (see Mencherini 1924; Pope-Hennessy 1979, p. 180; Lazzeri 1913; Baldini 2014). In 1432, Florence was designated as the monastery's protector with its wool guild, the Arte della Lana, responsible for facilitating donations to it, which explains the guild's shield of arms on the church. A 1451 papal indulgence by Nicholas V expedited the completion of the Chiesa Maggiore by 1470, only to have most of it destroyed by fire in 1472. Donations for its rebuilding dramatically increased after the fire, which perhaps created an opportunity for the monastery's caretakers to provide some artistic and decorative unity to a monastery that otherwise lacked formal harmony (Pope-Hennessy 1979, p. 180). The church was fully restored by 1509 .

Brothers at Franciscan monasteries rarely participated in artistic commissions as such decisions were often left to superiors, confraternities, or individuals and their families (Bourda 1996, 2004, esp. pp. 16-31 and 148-55). Given the expanded role of Florence in the maintenance of the monastery, it is no surprise to find prominent Florentine families supporting the rebuilding efforts at the monastery and as patrons for most of the altarpieces commissioned from Andrea della Robbia, another Florentine (Tripodi 2014). Other than the inclusion of family crests or names, there is no evidence of patron involvement regarding the La Verna altarpiece commissions. Four of the five altarpieces have inscriptions and indicate family sponsorship. Specifically, the Niccolini arms flank the inscription on the base of the Annunciation, declaring them as the work's sponsor. This is the first altarpiece commissioned after the Chiesa Maggiore fire, and it is usually dated on stylistic grounds between 1476 and 1479 (Tripodi 2014, p. 165; Marquand 1919, p. 30). The balustrade on the Adoration's tempietto is dated (1479) and identifies its patron as Jacopo Brizi of Pieve S. Stefano (Tripodi 2014, p. 165, n. 54; Paloscia and Bernacchi 1986, p. 48; Mencherini 1924, p. 676). Flanking the inscription on the Crucifixion are the arms of the prominent 
Alessandri family of Florence; Tommaso Alessandri's and Andrea della Robbia's names appear in the monastery's entrata e uscita in August 1481, the year given to the altarpiece (Miller 2010, pp. 163-64; Tripodi 2014, pp. 152-53). S.M. degli Angeli, the first building erected at the monastery and where Francis and his followers performed the daily mass, includes the Madonna della Cintola (Figure 10). This altarpiece was installed in the mid-1480s, and certainly by 1488 , when the Bartoli and Ruccellai families were joined by marriage, thus explaining the appearance of both family crests on the predella, which also includes banderole bearing angels and a tabernacle (Tripodi 2014, pp. 159-60; Marquand 1922, vol. I, p. 78). This is the only La Verna altarpiece with a tabernacle, which is appropriate given the chapel's original function. The inscriptions on scrolls in the predella all refer to John 6:51 (I am the living bread which came down from heaven; if any one eats of this bread, he will live forever; and the bread which I shall give up for the life of the world is my flesh) and the Eucharistic function of the altarpiece and church. The Ascension of Christ (c. 1490; Figure 11), originally intended for the high altar in the Chiesa Maggiore, is the only altarpiece without an inscription or family crest. It is regarded as a Medici family commission given that the presbytery and choir of the Chiesa Maggiore were under Medici patronage since 1457 (Domestici 1991, p. 76; Domestici 1995, p. 50; Gentilini 1994, p. 94). The work cannot date later than 1493 when it was mentioned by De Riciis in his visit to the monastery (Chiappini 1927, p. 332). When the altarpiece was moved to the nearby Ridolfi chapel in 1601, it is conceivable that if there had been Medici stemme, or an inscription, they were removed at this time. Two robbiane niche figures, St. Francis and St. Anthony Abbot, to the left and right on the chancel archway in the Chiesa Maggiore, are also considered Medici commissions and attributed to Andrea. The Ascension as the Chiesa Maggiore's high altarpiece is considered briefly at the end.

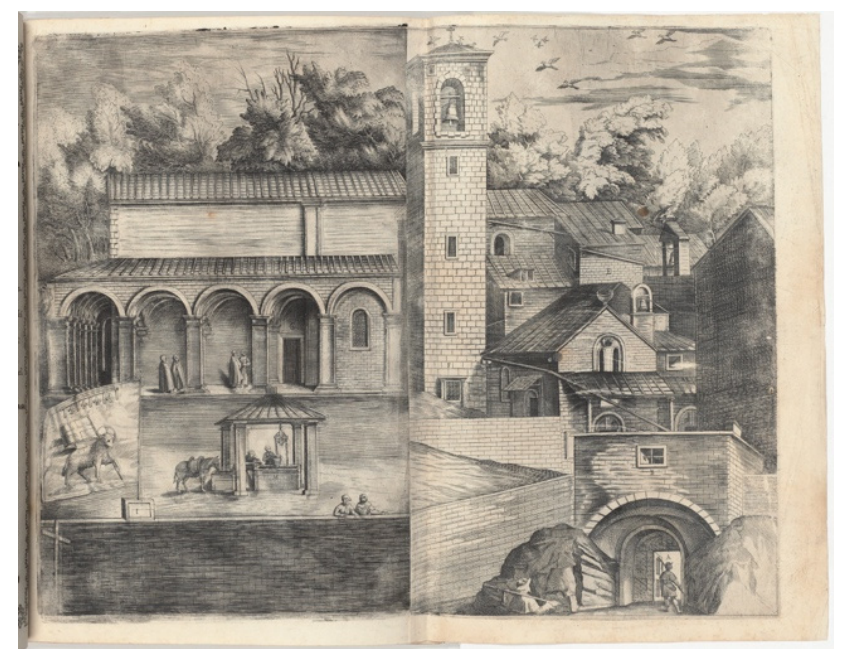

Figure 7. Jacopo Ligozzi, Chiesa Maggiore, plate D, engraving from Lino Moroni's Descrizione del Sacro Monte dell Vernia, 1612 (photo source: Courtesy National Gallery of Art, Washington).

Despite the different sponsoring families for Andrea's La Verna altarpieces, a sense of harmony in both style and theme was achieved, suggesting a degree of coordination that reflected Franciscan themes and tastes, possibly inspired by the influential St. Bernardino of Siena (c. 1380-1444) (Pope-Hennessy 1979, p. 184; Muzzi 1998, pp. 47-48; Salmi 1969). By at least 1474, Andrea established a relationship with the Franciscan church, and the Observant order, when he worked with the Ugurgieri family of Siena, during the rebuilding of St. Bernardino's church there, the Osservanza (Domestici 1995, pp. 47-48; Muzzi 1998, pp. 47-48). Andrea's Coronation of the Virgin (c. 1474) was made for the Ugurgieri chapel in the Osservanza and dates to the years immediately preceding the La Verna Annunciation. St. Bernardino of Siena appealed to reform-minded Observant Franciscans. He was known for his dedication to poverty, love of the Virgin Mary, and his YHS emblem (Pastor 1969, pp. 97, 233; Moorman 1988, pp. 369-83, 446; Rarick 1990, pp. 124-45). Like St. Francis, 
St. Bernardino emulated Christ's commitment to humility and poverty, and his faith thus mirrored Francis' values and devotion to Christ. Furthermore, Bernardino's sermons repeatedly characterized Francis as an alter Christus by drawing parallels between them, especially by emphasizing the stigmatization, a point that was sure to resonate at La Verna (Debby 2008, pp. 83-84). In short, Bernardino was extremely popular and influential, and whose flair and direct preaching style, in part, led to the relinquishment of many Conventual Franciscan convents to the Observants, including La Verna in 1431 (Barfucci 1991, p. 64; Ritsema van Eck 2017, p. 285; Tanzini 2012, p. 234). Andrea della Robbia's altarpieces at La Verna, created in the wake of St. Bernardino's canonization (1450), not surprisingly resonated with Bernardino-inspired, Observant Franciscan themes.

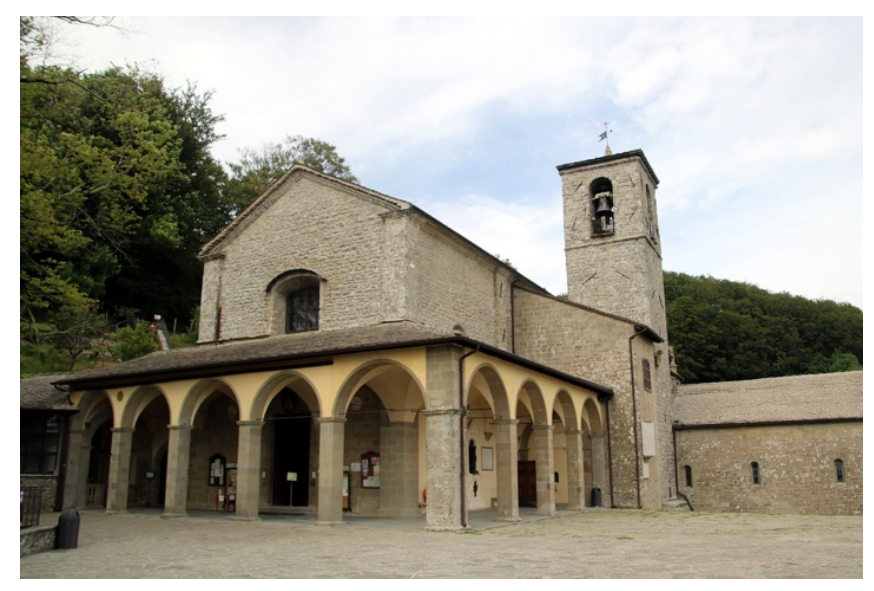

Figure 8. Exterior Chiesa Maggiore, La Verna (photo source: Mongolo1984, CC BY-SA 4.0, via Wikimedia Commons).

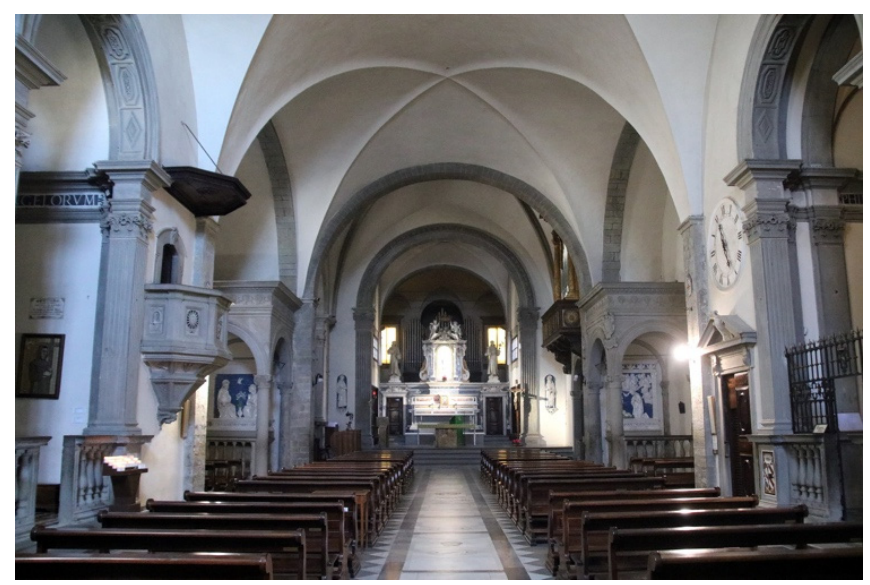

Figure 9. Interior Chiesa Maggiore, La Verna (photo source: Mongolo1984, CC BY-SA 4.0, via Wikimedia Commons). 


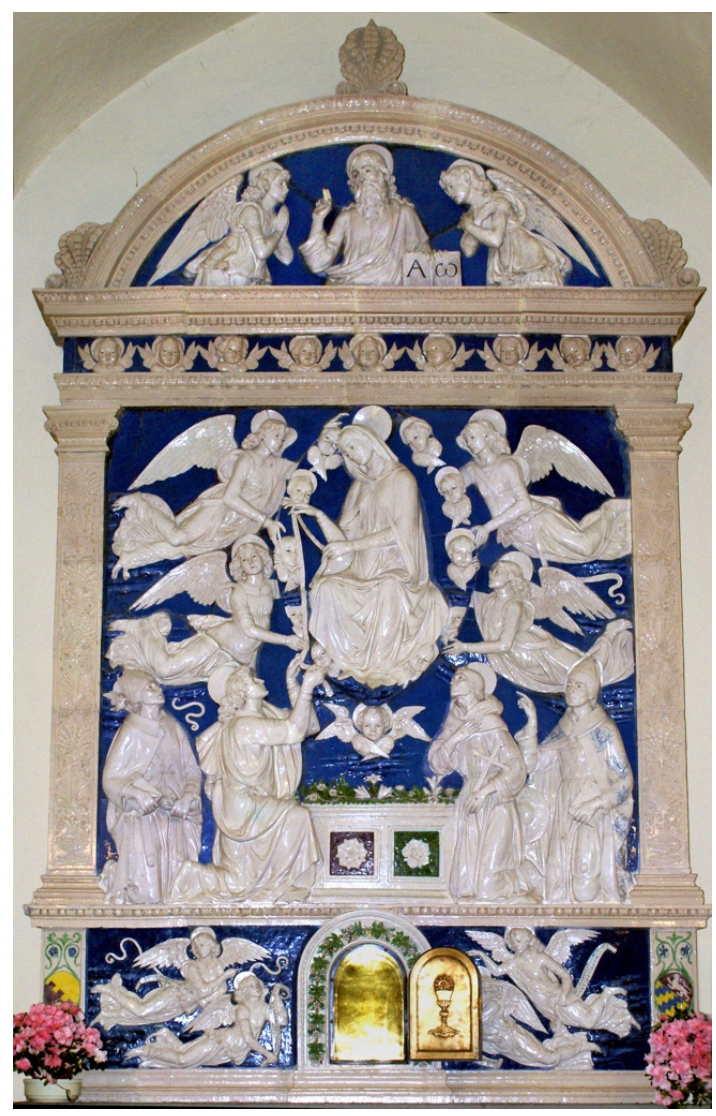

Figure 10. Andrea della Robbia, Madonna della Cintola, enamel terra cotta, Santa Maria degli Angeli, La Verna (photo source: Gunnar Bach Pedersen, Public domain, via Wikimedia Commons).

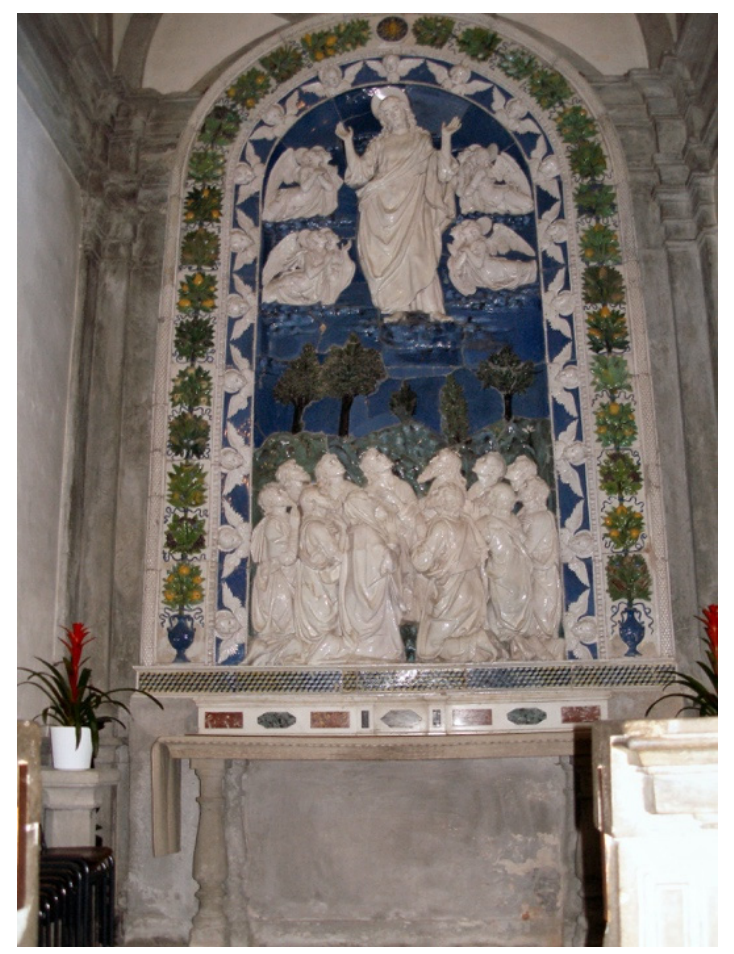

Figure 11. Andrea della Robbia, Ascension of Christ, enamel terra cotta, Chiesa Maggiore, La Verna (photo source: Gunnar Bach Pedersen, Public domain, via Wikimedia Commons). 


\section{Franciscan Theology and the Appeal of Enameled Terra Cotta}

Della Robbia's five La Verna altarpieces offer a sense of visual and thematic unity to the monastery due to their common medium and themes influenced by St. Bernardino of Siena, whose sermons often highlighted the worship of the Virgin. Pier Paolo Ugurgieri of Siena may have been instrumental in this coordination (Domestici 1991, p. 73). Pier Paolo Ugurgieri was associated with the artist as early as 1474 from Andrea's Coronation of the Virgin commission for his family's chapel in the Osservanza. Pier Paolo was provincial vicar of the Observant order and keeper of La Verna in 1472, at the outset of a post-fire rebuilding campaign of the Chiesa Maggiore, when Andrea's earliest altarpieces, the Annunciation and the Adoration (Figures 5 and 6) were created (Gentilini 1994, p. 90; Muzzi 1998, p. 43). From the start of this rebuilding, enameled terra cotta was the preferred medium for the monastery's ornament, and in the 1470s, this medium was practiced exclusively by the Della Robbia family of Florence. As a remote mountainous location, the monastery posed challenges of inclement weather and poor accessibility. From Vasari to present-day scholars, enameled terra cotta offered practical advantages for a location such as La Verna (Boucher 2001, pp. 14-16; Baldini 2012, p. 244). The novel medium tolerated weather fluctuations and even the largest of Andrea's works, the Crucifixion, made of 720 individual sections, could be transported safely by shipping those sections in several boxes from his Florence workshop to the monastery to be assembled on-site. The chronologically earlier Annunciation and Adoration altarpieces must have been perceived favorably, for the medium and artist were chosen for the monastery's subsequent high altarpieces in its three most public devotional buildings.

Composed of eighty-six interlocking pieces of enameled terra cotta, the Annunciation is considered one of Andrea's finest and most elegant reliefs. Across the aisle is the slightly more rectangular, ninety-five-piece Adoration altarpiece (1479). Within the relatively spare interior of the Chiesa Maggiore, the shiny blue and white altarpieces are prominent and seem to coordinate with each other visually and spatially. Each altarpiece is set within a tempietto which strengthens their physical and formal association and gives the impression they could be read as a pair (Domestici 1991, p. 73; Muzzi 2000, p. 517). Characteristic of Andrea della Robbia's style, both altarpieces have blue backgrounds with white figures in modest relief and a minimal use of accent colors, such as green for flower stems or hay. Both are framed in white, the Annunciation with a classical palmette motif, while the Adoration also includes Andrea's signature cherub heads along the top. God the Father appears in both but more modestly so in the balanced composition of the Annunciation and more boldly with additional angels in the Adoration. Compared to Andrea's three later altarpieces here, the Annunciation and Adoration are small and more rectangular with a horizontal composition. The Crucifixion, Madonna della Cintola, and Ascension include more color, are substantially larger, oriented vertically, and have a more narrative quality. That is, the compositions are animated with many more expressive and gesticulating figures that assist in narrating the scenes. By contrast, the Annunciation and Adoration are significantly more restrained.

Stylistic and compositional differences notwithstanding, the Della Robbia altarpieces are united by medium. Authors from Pliny the Elder to Lorenzo Ghiberti morally equated terra cotta with modesty, innocence, and humility, qualities which complemented Franciscan ideals of poverty and simplicity (Muzzi 1998, p. 46; Panzanelli 2008; Miller 2013, pp. 8-9; Cambareri 2016, p. 43). For instance, Fra Giovanni Dominici suggested such material associations when he advocated that domestic devotional objects be made of simple materials because costly materials could interfere with genuine piety (Domenici 1927, p. 35). Because Franciscans likewise upheld the virtues of humility and simplicity, these ideals were applied to church adornment. Andrea's sculpture in enameled terra cotta suitably matched Franciscan preferences.

Admittedly, though, Andrea's altarpieces are not simply baked clay. They are shiny, reflective, and brilliant. Andrea Muzzi contended that the relationship between the simple, lowly medium of terra cotta and Franciscan art appealed to the Franciscan desire for 
poverty and simplicity only on an intellectual level because the terra cotta sculptures were ultimately covered with enamel (Muzzi 1998, p. 46). Nevertheless, the reflective white of the Della Robbia enamel could also symbolize the "invisible light of God" as described in Marsilio Ficino's De Lumine, in which the luminous reflections of enamel are equated with spiritual splendor and purity (del Bravo 1973, p. 26; Gentilini 1992a, pp. 101-6). Enameled terra cotta satisfied, at least theoretically, the desire for a humble, simple art form whose luminescence was also theologically associated with divine light and purity (Gentilini 1992b, p. 445; Kupiec 2016, pp. 106-7). The spiritually symbolic overtones of the white enamel glaze harmonized with St. Bernardino's Franciscan reform sensibilities in which white enamel was a spiritual metaphor for light, God, purity, clarity, and innocence (Domestici 1995, p. 47). Light was an essential symbol for St. Bernardino. His emblem was an emblazoned YHS monogram (Holy Name of Jesus), which depicted "rays of light" emanating from the monogram, often in yellow or gold, on a blue ground. This visual symbol of light was directly above and behind his head when he preached and became a popular devotional focal point for his congregants (Debby 2008, p. 83). The radiating YHS emblem was augmented by St. Bernardino's sermons which connected light and goodness. For example, he preached how "White is shining and resplendent: just as the virtuous soul is radiant and shines with the grace of God" (St. Bernardino of Siena 1935, p. 168). The writings of the Dominican St. Antoninus, archbishop of Florence from 1446 to 1459, also associated white and purity, underscoring both the popular reach and influence of St. Bernardino but the growing familiarity of shining white as a symbol for purity and divinity (Kupiec 2016, pp. 106-7; Gentilini 1992a, p. 38). Catherine Kupiec elaborates that because white Della Robbia enamel literally reflected light, it could be conflated with light itself; thus Della Robbia altarpieces with enameled white figures could further communicate Christ as the Light of the World as from John 8:12 (2016, p. 106).

The symbolic meaning of white enameled terra cotta was broadly understood by fifteenth-century audiences, which legitimized among the faithful the outwardly sumptuous appearance of the lustrous and brilliant material. Pier Paolo Ugurgieri and other Franciscans could seize upon this familiar understanding and the words of St. Bernardino's sermons and transform his metaphor of light into tangible reality through Andrea's altarpieces. Taken together, the clay as well as the white enamel were understood as humble and pious materials and perfectly suited to the Franciscan caretakers at La Verna.

\section{The Annunciation and Adoration: Inscriptions, Invocations, and Interaction}

While the material of the altarpieces satisfies some general values of the Observant Franciscans, Andrea's altarpieces at La Verna thematically, textually, and iconographically also demonstrate Andrea's sensitivities to theological concerns and Renaissance devotional practices. Specifically, the Annunciation and the Adoration illustrate the Franciscan perspective of the Incarnation where Christ's humanity and flesh pre-existed in the sinless Virgin. For instance, the Franciscan monk St. Bonaventure (c. 1217-1274), who wrote his Journey of the Mind to God (1259) at La Verna, also stressed the Word and Incarnation in his theological writings and sermons. St. Bonaventure claimed that at the Incarnation it was "not simply that God became flesh, but that the Word, specifically, became flesh" and the flesh came from the Virgin Mary (Hayes 1994, pp. 85-86; Muzzi 2000, p. 521; Bynum 1986, p. 422). Furthermore, Bonaventure, like the anonymous Franciscan author of the Meditations on the Life of Christ, encouraged the imitatio Christi, the imitation of Christ. The Meditations urged the reader (viewer) to identify emotionally with the protagonists, particularly Christ and the Virgin (imitatio Mariae). This text also explicitly stated, "let us contemplate the life of the Virgin in whom the Incarnation was effected" (Bonaventura 1961, p. 10). Such empathetic imitation was a popular, contemporary form of devotion generally known as the devotio moderna. Andrea della Robbia responded to such influences at La Verna where the concept of the Incarnation is similarly pronounced in these two Chiesa Maggiore altarpieces, and in which the significance of the Virgin and the Word/verbum is distinct and crucial to their interpretation. 
To address Franciscan theological and devotional needs, Andrea included inscriptions in all but one of the altarpieces at La Verna, which clarify the interpretation and foster worshipper interaction with the works and space. The La Verna altarpieces notwithstanding, base inscriptions of this nature are not regular features on Andrea della Robbia's altarpieces. Of the others that include inscriptions, such as the Osservanza Coronation of the Virgin, mentioned above, or the Madonna and Child between Saints in the Medici Chapel in S. Croce (c. 1480), the inscriptions tend to identify the subject or patron. In the case of the Osservanza altarpiece, the inscription identifies the subject on a scroll within the composition. Notably, however, a Della Robbia Crucifixion at Santa Maria Primerana in Fiesole (c. 1505-1550) duplicates the inscription from the La Verna Crucifixion. Nevertheless, the La Verna base inscriptions are distinct. I suggest that the earliest two robbiane altarpieces in the Chiesa Maggiore, the Annunciation and Adoration altarpieces, were intended visually, thematically, and textually as a pair to prompt pilgrim or beholder engagement. The altarpieces are across the nave aisle from each other (left and right, respectively) and, facing the entrance, are visible to the arriving worshipper (Figures 7-9). Thus, rather than flush against the side walls of the church, the altarpieces are perpendicular to them, thus increasing their visibility from the church's entrance. Specifically, the altarpieces coordinate within church environment and invite devotion through text and image.

The base of the Annunciation altarpiece reads: ECCIE $\bullet$ A(N)CILLA $\bullet$ DO(MIN)I - FIAT • MIHI • SECV(N)DVM • VERBVM • TVV(M) (Behold the handmaid of the Lord; let it be done according to Thy Word). This text from Luke 1:38 is the Virgin Mary's response to Gabriel's announcement that she will bear the Christ child. The inscription thus identifies the image above as the moment after Gabriel's announcement when upon Mary's acceptance, the Incarnation occurred, and the Word was made flesh. Andrea atypically placed the Virgin on the composition's left with Gabriel at the right, who looks to the Virgin, perhaps listening to her response. A half-length figure of God the Father looks down on Mary, who just received her answer to Gabriel's announcement. The descending Holy Spirit indicates Mary's answer and acceptance of her role as the mother of God and the moment of the Incarnation. Andrea della Robbia included some traditional Annunciation motifs, such as the symbolic lilies separating the two figures and the Virgin reading, presumably Isaiah's prophecy of the virgin birth and Incarnation. However, placing the Virgin Annunciate on the left is uncommon in Italian Renaissance art (Denny 1977, pp. 111-13). By reversing her traditional location, the Virgin Mary's active speaking role is emphasized with her words on the base moving from left to right, establishing a narrative flow, and underscoring the Virgin as the vehicle of the Incarnation (Denny 1977, p. 136). It is perhaps noteworthy that Andrea never again repeated this format. With the Virgin at the composition's left, she is more legible from the entrance and faces the center of the church. Conceivably, this arrangement supports the left-to-right reading of the text as well as the site-specific nature of the work.

The Latin inscription on the base of the Adoration is essentially the immediate response to the Annunciation altarpiece: VERBVM CARO • FATTV(M) • EST $\bullet$ DE VIRGINE • M(ARI)A (the Word was made flesh from the Virgin Mary). Two points are clearly made in the Adoration inscription - not only is the Word, from God the Father, made flesh, but the flesh is of the Virgin Mary. God the Father with flanking half-length angels bearing a banderole of music reading Gloria in Excelsis Deo makes for a rather dynamic composition. The remaining imagery initially appears as a traditional Adoration or Nativity scene, but the base inscription defines it as the Incarnation through its reference in this case to John 1:14: the Word was made flesh and dwelt among us. Although the inscription alludes to John, the subtle deviation from it once again emphasizes the role of the Virgin Mary: the Word was made flesh from the Virgin Mary.

Zuzanna Sarnecka noted a similar shift in emphasis when it comes to this subject and inscription on domestic devotional objects (Sarnecka 2019, pp. 176-77). Relatedly, the small-scale objects she considers are glazed terracotta for the home environment where they can be picked up and touched. Compositionally, the Adoration is like many other 
smaller versions by Andrea and his uncle Luca della Robbia, with the haloed Child on a wedge of green hay off-center to subtly shift the focus to the adoring Virgin, whose head is nearly in the center of the composition. The compositional type had become popular in the 1450s as a "visual metaphor for the Incarnation, penitence, and eremitical religious devotion" (Holmes 1999, p. 172; Ruda 1993, pp. 218-28). Essentially the visual language of the Adoration or Nativity symbolized the Incarnation, and in the case of the La Verna altarpiece, the inscription literally defines it so. The popularity of this subject for the domestic environment likely accounts for the many smaller versions of this subject by Della Robbia (Sarnecka 2019). In fact, the Metropolitan Museum of Art's Virgin Adoring the Christ Child (after 1479) is described as a variant of the large Brizi (La Verna) Adoration (Figure 12); this smaller-scaled work would have been suitable for home worship, but as with most such objects, we cannot determine a specific household. Nevertheless, images of the Virgin and Child, in all media, are found in abundance in domestic inventories from the Italian Renaissance and frequently noted in bedchambers (Cooper 2006; Sarnecka 2020, p. 6). Another interesting parallel between the La Verna Adoration and other Della Robbia versions, such as Luca della Robbia's smaller-scaled Nativity with Gloria in Excelsis (c. 1470; Boston Museum of Fine Arts) or the Della Robbia Nativity panel variously attributed to one of Andrea's sons in S. Maria degli Angeli, is the inclusion of musical references (Sarnecka 2019, pp. 177-78).

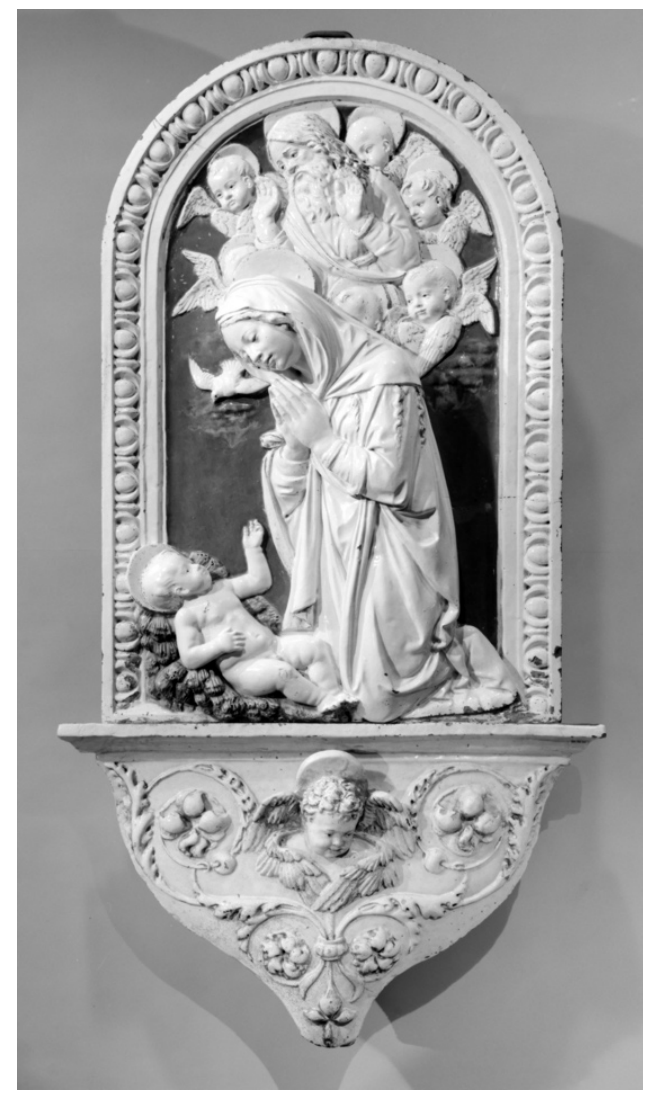

Figure 12. Virgin Adoring the Christ Child, enamel terracotta; workshop of Andrea della Robbia, after 1479 (photo source: Metropolitan Museum of Art, Open Access Policy, public domain).

Medieval and early Renaissance literature, such as the Golden Legend or the Meditations on the Life of Christ, advocates reading the altarpieces as visual and textual commentaries on the Incarnation. For example, the Golden Legend's account of the Annunciation explicitly connected it with the Incarnation: "And it was fitting that an angel should announce the Incarnation, because in this guise the fall of the angels was repaired ... The Incarnation in sooth took place to repair not only the fall of man, but the ruin of angels ...." (da 
Voragine 1969 , p. 204). The Meditations also expressed how the Incarnation was immediate upon the Virgin's acceptance: "Then the son of God forthwith entered her womb without delay ... At that very point the Spirit was created and placed into the sanctified womb" (Bonaventura 1961, p. 19). Andrea's Annunciation depicts the moment after Gabriel's announcement, the Annunciate's response and Incarnation. Through the focus on her response rather than Gabriel's address, the altarpiece visually and textually promotes devotion to the Virgin. The inscriptions on both altarpieces fundamentally augment the interpretation of the image rather than merely identify the subject.

Roger Tarr discussed Ambrogio Lorenzetti's Annunciation (1344; Figure 13) as a relevant example whereby the painting's text elaborates on the image by eliciting a verbal or read response from the image's beholder (Tarr 1997, p. 77; Van Dijk 1999). The visible "spoken words" within Lorenzetti's Annunciation also reflect on the Incarnation where instead of announcing that the Virgin will bear the Christ Child, Gabriel's words on the painting read "Non est (erit) impossibile apud Deum omne verbum" (Nothing is impossible for God's Word) and Mary's reply, "ecce ancilla domini" (Behold the handmaid of the Lord) (Tarr 1997, p. 225). Their words are worked into the gold ground of the painting as if they were actually spoken, issuing from their mouths. Mary's response in Lorenzetti's work leaves unsaid Luke's remaining passage, let it be done according to Thy Word (Tarr 1997, p. 226). Tarr contended the spoken word verbum in this passage becomes "the vehicle for the transmission of God's will" (1997, p. 226). The complete phrase in Andrea's Annunciation makes clear the Virgin has accepted her role according to the Word and her significance in the Incarnation. Verbum, both spoken and written in the Annunciate's expanded response in the La Verna Annunciation, literally supports the divine mystery above. The bold placement of the text across the base, furthermore, implies more than a passive spectator before the altarpiece but rather one who will read or speak the Virgin's spoken words as well. Jessica Richardson elaborated on Tarr's scholarship to suggest that "depicted speech" need not be contained within the pictorial space itself but rather can extend into the viewer's space, where the beholder in front of the work completes its meaning, prayer, or ritual (2019, p. 354).

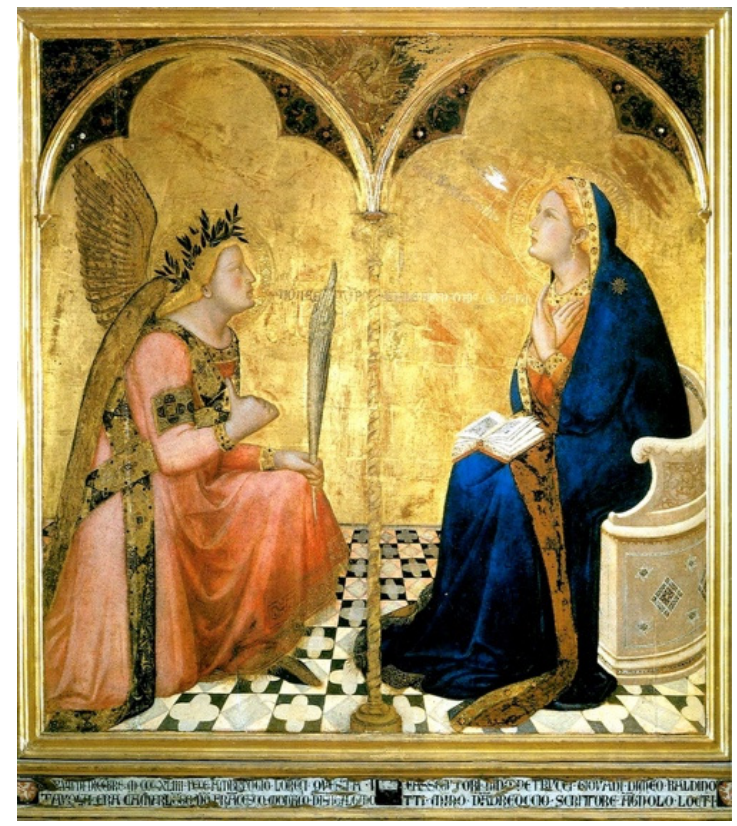

Figure 13. Ambrogio Lorenzetti, Annunciation, panel. Siena, Pinacoteca (photo source: Public domain, via Wikimedia Commons).

Biblical inscriptions were familiar features on Renaissance religious images to identify subjects, to make visible words spoken by the image's protagonist, adding depth to an 
image's interpretation through invocations that invite the beholder to participate in the event (Richardson 2019; Wallis 1973). Including the Virgin's words as the inscription on the La Verna Annunciation emphasizes the Incarnation and underscores her central role in it. Moreover, when the Annunciation is read together with the Adoration, the inscriptions invite prayer from the worshipper in the space before and between the two altarpieces. The pilgrim entering the Chiesa Maggiore, standing in the nave between these sculpted altarpieces, physically connects them and experientially creates additional meaning.

The Adoration's inscription also emphasizes that the "Word was made flesh from the Virgin Mary", thus highlighting her role in the Incarnation, complementing her centrality in Andrea's composition. This inscription might refer to a significant passage from the Nicene Creed recited at Mass, " . . and was incarnate by the Holy Spirit of the Virgin Mary, and was made man." Despite similarities between the inscription and the Creed, I would suggest that the Angelus prayer offers a closer parallel. In fact, the Angelus prayer's most relevant passages unite the inscriptions on both the Annunciation and Adoration altarpieces. The Angelus, originally recited in the evening, at the supposed hour of the Incarnation, is a recitation that evolved among Franciscans, and, in fact, was encouraged by St. Bonaventure as a prayer dedicated to the Incarnation (Thurston 1901, 1907):

Behold the handmaid of the Lord

Be it done according to thy Word.

The Word was made flesh

And dwelt among us

These passages from the Angelus, borrowing from both Luke and John, are then followed by Hail Marys, and the remaining prayer is likewise devoted to the Incarnation. The specific passages from the Creed and, more convincingly, the Angelus prayer support the visual and textual evidence in both altarpieces and suggest an interaction with and response (vocal or read) by the worshipper/pilgrim before the altarpieces as encouraged by contemporary literature and devotional practices. Regarding the Angelus, for instance, one must imagine a pilgrim, who, according to tradition, would pause at the compline bell to offer devotion to the Incarnation by reciting this prayer, verses of which are referenced on Andrea's altarpieces. The inscriptions, particularly the text on the Annunciation, can refer to a viewer and reader, as well as to a speaker reciting the Virgin's spoken response/inscription as one's own prayer, who in an extreme act of piety empathizes with Mary by speaking her words. The sense of sound, real or imagined, augments the worshipper's experience before the altarpieces. The musical references in the Adoration also simulate an auditory experience, but one that is loud and joyful, even if only imagined.

By considering the Annunciation and Adoration as a pair or as pendants, the beholder physically facilitates the interaction between the altarpieces. Allie Terry-Fritsch describes such an experience at an early sixteenth-century Franciscan pilgrimage site outside of Florence, dubbed the New Jerusalem at the sacro monte of San Vivaldo in Tuscany (TerryFritsch 2020, pp. 161-215). Visitors who made the pilgrimage to San Vivaldo visited its various spaces and structures built to create a simulated experience of visiting the Holy Land and its sacred locations. Among the visual experiences are a pair of relief sculptures on the exteriors of two buildings, an Ecce Homo and a Crucifige, between which the pilgrim would physically mediate the "spatial gap" between the works creating an immersive environment for the beholder to contemplate numerous devotional scenarios (Terry-Fritsch 2020, pp. 193-94). As a sacro monte, La Verna, too, was described as a Jerusalem in the West, but its sites of devotion were far less developed than San Vivaldo. However, La Verna had the virtue of being the actual site of St. Francis' stigmatization as well as being formed at the moment of the Crucifixion. It was believed the formation of La Verna's deep chasms and fissures occurred at the very hour of Christ's death when the Gospel says that the rock split, Matthew 27: 50-52 (Ritsema van Eck 2017, p. 259). Nevertheless, the devotional practices before and between images at these modestly later sites offer a meaningful way to consider the altarpieces in the Chiesa Maggiore. Worshippers arriving 
at La Verna, physically invested in the trek up the mountain, were eager to experience the environment where St. Francis lived and prayed (practices they sought to emulate). Within the austere interior of the Chiesa Maggiore, the two altarpieces, left and right of the nave, read like a prayer book or at least hint at such object association and familiar form of domestic devotion; both altarpieces and prayer books inspired devotional reading and engagement with imagery. Virginia Reinburg offers a useful analogy on medieval books of hours whereby the book provides the "personal script for prayer-as like the two panels of a diptych" (2012, pp. 214-17). Furthermore, in books of hours, the Annunciation was usually the first image illustrated and it was then followed by an invocation or "dialogue" with God (Reinburg 2012, pp. 214-17). The diversity of objects used as meditational prompts in the Renaissance encourages a kind of cross-fertilization whereby one form could influence or inform how other forms were used and interpreted. The prayer book is also instructive for it reminds us that devotional reading rarely required a command of Latin or grammar, was often performed before images, and was a form of prayer that could be silent or vocal, in which the written words might only serve as initial prompts for the most familiar prayers that one "already knew by heart" (Reinburg 2012, p. 111).

Worshippers visiting La Verna were already conditioned by their everyday devotional routines practiced in their homes or hometown liturgical settings, and they brought those familiar rituals and practices with them to La Verna. Subsequently, the beholder at La Verna standing between the Annunciation and Adoration altarpieces had various approaches and strategies by which they could experience the works and space, which in turn could motivate deeper meaning and engagement. The tactility of the relief sculptures, their reflective surfaces, and their inscriptions as prompts for prayer, "activate and emplace" the worshipper at La Verna who drew upon a tradition where images were cues for various devotional activities to aid their meditative practices (Terry-Fritsch 2020, p. 19; Williamson 2004, pp. 386-87). These traditions included prayers before the popular Marian images found in fifteenth-century homes, often lit by candles during private devotions (Sarnecka 2019; Kupiec 2016, pp. 112-16). Given the similarity of theme and potentially material, such domestic works might have informed how visitors engaged with and perceived the Chiesa Maggiore altarpieces, especially when they were likewise illuminated by candles on the altars before them. This reciprocity of religious experiences and objects seems especially meaningful for domestic religious images in enameled terracotta or majolica as it could blur the distinction between familiar and unfamiliar settings. When one returned home from their visit to the sacro monte of La Verna, for instance, their domestic devotional objects could have additional resonance because of this new experience. Zuzanna Sarnecka describes curious majolica model chapels and sanctuaries that were produced mostly in Urbino in the sixteenth century (Sarnecka 2020). One such example is a model La Verna sanctuary that dates to 1521 (Sarnecka 2020, pp. 12-13). The unknown owner might very well have used the miniature sanctuary to memorialize a pilgrimage to the monastery, like a devotional souvenir, to embark on a "mental pilgrimage" by visually navigating the different buildings in the model monastery and thereby interacting with it as a devotional aid (Sarnecka 2020).

In 1493, Fra Alexandro de Riciis described practices that demonstrated how such cultural emplacement and imaginative connections occurred with worshippers to La Verna's most sacred site in the Chapel of the Stigmata with its Crucifixion altarpiece. The importance of location resounds potently in this chapel, and the Crucifixion binds the subject to the location where St. Francis, meditating on Christ's suffering, saw a vision of the seraphic crucifix and received the stigmata (Miller 2010, p. 164). The Crucifixion altarpiece served as a visual and textual prompt for the beholder, who would stand on the same rock as Francis to recreate and emulate his meditations and his visionary experience. The beholder experience in the Chapel of the Stigmata offers a model for how a beholder could engage with the Annunciation and Adoration altarpieces. Although lacking the profundity that resonates at the Chapel of the Stigmata, the Chiesa Maggiore was the largest public devotional church on the mountain, built with the intention of receiving eager worshippers. 
Just like the model sanctuary of La Verna mentioned above that could be picked up and explored with hands and eyes, visiting worshippers to the actual sanctuary likely sought to engage with the entire space of the remote sanctuary, including the Chiesa Maggiore.

Were one to enter the Chiesa Maggiore in the 1480s, one would see the two tempietti housing and drawing attention to the Annunciation and the Adoration. Because they are visually and thematically related, one can imagine the worshipper connecting them, engaging with the altarpieces and the space. By 1493, the high altarpiece in the Chiesa Maggiore, the Ascension of Christ (Figure 11), was in place. The effect must have been stunning, with the Annunciation and the Adoration essentially flanking the much larger Ascension (680 pieces) between them. Compared to the flanking altarpieces, the Ascension is taller, more colorful, and includes many more full-length figures. The composition depicts the apostles and the Virgin Mary in the lower half of the altarpiece, closer to the beholder, and the ascending Christ flanked by three-quarter-length angels are in the upper half. The figures are more animated, expressive, and in bolder relief than Andrea's work of the 1470s. The shape of the altarpiece echoes that of the chancel arch that originally framed the work when it was at the high altar, suggesting the artist and his workshop accommodated the space of its intended location. Without an inscription, one can only speculate on how the beholder might have interpreted the Ascension especially in the context of the Annunciation and Adoration. While these two earlier works readily function as a pair, regardless of the presence of the high altarpiece, how might the Ascension function with the pair? Visually and spatially, the three altarpieces read as a triptych across the space of the Chiesa Maggiore, with the Annunciation and Adoration as the "outer wings" to the central panel, for instance. Thematically, the "wings" of this triptych mark the beginning of Christ's mortal life, while the Ascension marks the end of his life on earth. Passages from the Golden Legend and the Meditations on the Life of Christ promoted a reading of all three subjects together (da Voragine 1969, p. 290; Bonaventura 1961, pp. 381-82). For example, when referring to those who ascended with Christ, Jacobus da Voragine wrote of "certain angels who did not have full knowledge of the Mystery of the Incarnation, Passion, and Resurrection; and seeing the Lord ascending into Heaven by his own power, with a multitude of angels, and of holy men, they wondered at the mystery of the Incarnation and the Passion ... " (1969, p. 290). Conceivably, then, the worshipper could continue to engage the space of the Chiesa Maggiore with the third altarpiece, one that also coordinated visually and possibly thematically with the Annunciation and Adoration.

\section{Conclusions}

While Fra de Riciis' text is the earliest visitor account to the monastery after Andrea's altarpieces were completed, the Ligozzi engraving and Moroni text are evidence of performative devotional practices at La Verna extending into the seventeenth century (Chiappini 1927, p. 333; Miller 2010, p. 168; Conigliello 1999, pp. 25-26). As the earliest chronicle, however, De Riciis' description of an interactive relationship between worshipper, altarpiece, and liturgical space can extend to the Chiesa Maggiore. As popular as Andrea's Adoration was, Andrea never repeated it as an altarpiece for a church (only smaller-scale versions likely for home worship); Andrea also never repeated the composition of the La Verna Annunciation for an altarpiece. These altarpieces were unique in Andrea's prolific career, and I suggest their compositional arrangements may have been determined by the physical context of the church. As well, I propose they were intended to be read and understood together as a pair in this distinctively Franciscan context where their interpretation was enabled by the worshipper who made meaning of them through their proximal relationship. These interpretations depend upon the worshipper interacting with the images and engaging in the dialogue between the altarpieces as indicated by their inscriptions. Engagement of this kind was described at later Italian pilgrimage sites and sacri monti in the early sixteenth century. A 1514 Franciscan treatise for the pilgrim to Sacro Monte at Varallo, for instance, directed the worshipper to participate in the sacred dramas portrayed in the sculptures as if they were occurring immediately before the pilgrim at that very 
moment (Shearman 1992, pp. 41-42). Furthermore, mentioned above, at the Franciscan New Jerusalem of San Vivaldo, a robust spatial and visual program was developed to likewise engage the pilgrim's mind, body, and imagination (Terry-Fritsch 2020, chp. 4). La Verna is distinctive as a Franciscan venue due to its renowned history and location, and that history explains its selective use of devotional imagery and in a material that fittingly supported Franciscan ideals of humility and purity. The Della Robbia altarpieces inspired prayer and devotion through their placement, inscriptions, and awareness of contemporary devotional practices and objects such as domestic Marian images and prayer books.

La Verna is a profound, yet remote site of Franciscan veneration and pilgrimage. However, despite its remoteness, the fifteenth-century visitor to La Verna standing before its altarpieces would have understood to a greater or lesser degree the type of active devotion expected before religious images and would have employed familiar strategies by which to engage with the divine. Beholders imagined themselves as participants in visual and textual depictions of holy events to fully apperceive the emotions and experiences of Jesus or the Virgin (Johnson 1994, pp. 282-83; Baxandall 1988, pp. 40-41). The events of St. Francis' own life provided vivid examples of this manner of devotion. Visual cues within Andrea's altarpieces also reinforce their textual interpretations and the participatory role of the worshipper. The compositions and inscriptions of the Annunciation and Adoration support a central Franciscan tenet, the Incarnation, in which the consequences of the Annunciate's visible speech in one altarpiece are manifested in the other, the Adoration. The thematic parallels potentially explain the compositional placement of the Virgin, where the Virgin from each altarpiece faces the other, forming visual bookends to the thematically related content they enclose. In between the altarpieces, in the nave of the Chiesa Maggiore, the beholder connects the two works, visually, physically, and through prayer as prompted by their inscriptions.

With much of the sanctuary's growth having occurred in the fifteenth century, the sacro monte of La Verna became the "template" for other spiritual retreats, other "new Jerusalems" in the West (Ritsema van Eck 2017, p. 285). La Verna anticipated other devotional pilgrimage retreats by aiding the faithful in their quest to engage and identify with holy personages and events. As a fifteenth-century precedent to those later ensembles, Andrea dell Robbia's La Verna altarpieces served as meditative works for worshippers who moved through its spaces, reflecting on and emulating St. Francis' veneration of Christ and the Virgin Mary. With inscriptions that are more than scene identifiers, the Annunciation and Adoration altarpieces in the Chiesa Maggiore promoted devotion to and empathy with the Virgin Mary by allowing the worshipper to imitate her response and reflect on the significance and consequences of the Word.

Funding: This research received no external funding.

Institutional Review Board Statement: Not applicable.

Informed Consent Statement: Not applicable.

Data Availability Statement: Not applicable.

Conflicts of Interest: The author declares no conflict of interest.

\section{Notes}

1 For a thorough history of the monsatery, its transition to the observant rule, and its place in the evolution of sacri monti, see Ritsema van Eck (2017), pp. 247-86; Baldini (2012).

\section{References}

Baldini, Nicoletta. 2009. The Delia Robbia. Arezzo. The Burlington Magazine 151: 416-17.

Baldini, Nicoletta. 2012. Indagini d'archivio sui rapporti fra il convento della Verna e la committenza artistica aretina fra il 1384 e il 1432. In Altro Monte non ha più santo il mondo. Storia, architettura ed arte alla Verna dalle origini al primo Quattrocento. Edited by Nicoletta Baldini. Chiusi della Verna: Atti del Convegno di studi, Convento della Verna, pp. 241-56. 
Baldini, Nicoletta, ed. 2014. Altro Monte non ha più santo il mondo. Storia, architettura ed arte alla Verna fra il XV ed il XVI secolo. Chiusi della Verna: Atti del Convegno di studi, Convento della Verna.

Barfucci, Mario Bernardo. 1991. Chiusi in Casentino e la Montagna a della Verna. In Chiusi della Verna: Guida al Santuario ed al territorio, al patrimonio storico, artistico ed alle sue tradizion. Firenze: Arnaud Editore, pp. 45-70.

Baxandall, Michael. 1988. Painting and Experience in Fifteenth Century Italy, 2nd ed. Oxford and New York: Oxford University Press.

Bonaventura, St. 1961. Meditations on the Life of Christ. Edited by Isa Ragusa and Rosalie Green Ragusa. Translated by Isa Ragusa. Princeton: Princeton University Press.

Boucher, Bruce. 2001. Italian Renaissance Terracotta: Artistic Revival or Technological Innovation. In Earth and Fire: Italian Terra Sculpture from Donatello to Canova. Edited by Bruce Boucher. New Haven and London: Yale University Press, pp. 1-32.

Bourda, Louise. 1996. Franciscan Order: Patronage. In Dictionary of Art. Edited by Jane Turner. New York: Grove, vol. 11, pp. 711-13. Bourda, Louise. 2004. The Franciscans and Art Patronage in Late Medieval Italy. Cambridge: Cambridge University Press.

Boyd, Rachel Elizabeth. 2020. Invention, Collaboration, and Authorship in the Renaissance Workshop: The Della Robbia Family and Italian Glazed Terracotta Sculpture, Ca. 1430-566. Ph.D. dissertation, Columbia University, Manhattan, NY, USA.

Bynum, Carolyn Walker. 1986. The Body of Christ in the Later Middle Ages: A Reply to Leo Steinberg. Renaissance Quarterly 3: $399-439$. [CrossRef]

Cambareri, Marietta. 2016. Della Robbia: Sculpting with Color in Renaissance Florence. Boston: MFA Publications.

Chiappini, Anicetus. 1927. De vita et scriptis Fr. Alexandri de Riciis. Archivum Franciscanum Historicum 20: 314-35.

Classen, Constance. 2012. The Deepest Sense: A Cultural History of Touch. Champaign: University of Illinois Press.

Conigliello, Lucilla. 1999. Le Vedute del Sacro Monte delle Verna: Jacopo Ligozzi pelligrino nei luoghi di Francesco. Florence: Polistampa.

Cooper, Donal. 2006. Devotion. In At Home in Renaissance Italy. Edited by Marta Ajmar-Wollheim and Flora Dennis. London: V\&A Publications, pp. 190-203.

da Voragine, Jacobus. 1969. The Golden Legend. New York: Arno Press.

Debby, Nirit Ben-Aryeh. 2008. The Santa Croce Pulpit in Context: Sermons, Art and Space. Artibus Et Historiae 57: 75-93.

del Bravo, Carlo. 1973. L'umanesimo di Luca della Robbia. Paragone 285: 3-34.

Denny, Don. 1977. The Annunciation from the Right from Early Christian Times to the Late Sixteenth Century. New York and London: Garland Publishing.

Domenici, Giovanni. 1927. Regola del governo di cura familiar, parte quarta: On the Education of Children. Translated by Arthur Basil Coté. Washington, DC: Catholic University of America.

Domestici, Fiamma. 1991. Il patrimonio artistico. In Chiusi della Verna: guida al Santuario ed al territorio, al patrimonio storico, artistico ed alle sue tradizione. Firenze: Arnzud Editore, pp. 71-80.

Domestici, Fiamma. 1995. I della Robbia a Pistoia. Firenze: Franco Cantini Editore.

Gentilini, Giancarlo. 1992a. I della Robbia: La scultura invetriata nel Rinascimento. Florence: Cantini, vol. I-II.

Gentilini, Giancarlo. 1992b. Sulle prime tavole d'altare in terracotta, dipinta e invetriata. Arte Christiana 753: 439-50.

Gentilini, Giancarlo. 1994. Sculture di luce. FMR: Edizione Italiana 103: 83-104.

Gentilini, Giancarlo, ed. 1998. I Della Robbia e l'arte nuova' della scultura invetriata. Florence: Giunti Editore, Exh. Cat. Basilica di Sant'Allessandro, Fiesole.

Giorgi, Anna. 2012. Dal primitivo insediamento alla Verna dell'Osservanza. In Altro Monte non ha più santo il mondo. Storia, architettura ed arte alla Verna dalle origini al primo Quattrocento. Edited by Nicoletta Baldini. Chiusi della Verna: Atti del Convegno di studi, Convento della Verna, pp. 45-68.

Hayes, Zachery. 1994. Bonaventure: Mystery of the Triune of God. In The History of Franciscan Theology. Edited by Kenan B. Osborne. New York: St. Bonaventure University, pp. 39-125.

Holmes, Megan. 1999. Fra Filippo Lippi: The Carmelite Painter. New Haven and London: Yale University Press.

Hykin, Abigail. 2017. The Conservation of della Robbia Sculpture: An Exhibition as Initiator of Work. In Objects Specialty Group Postprints. Edited by Emily Hamilton, Kari Dodson and Tony Sigel. Washington, DC: American Institute for Conservation of Historic and Artistic Works, vol. 24, pp. 1-25.

Johnson, Geraldine. 1994. In the Eye of the Beholder: Donatello's Sculpture in the Life of Renaissance Italy. Ph.D. dissertation, Harvard University, Cambridge, MA, USA.

Karmon, David. 2016. The Sacro Monte at Varallo and the Choreography of an Olfactory Landscape. Future Anterior: Journal of Historic Preservation, History, Theory, and Criticism 2: 57-75.

Kupiec, Catherine Lee. 2016. The Materiality of Luca della Robbia's Glazed Terracotta Sculptures. New Brunswick: Rutgers, The State University of New Jersey.

Lazzeri, Zefferino. 1913. La Verna: Il commune di Firenze e l'arte della lana. In La Verna: Contributi Alla Storia e Documenti: Ricordi del Settimo Centario della Donazione del Sacro Monte a S. Francesco, 1213-913. Arezzo: Cooperativa Tipografica, pp. 275-94.

Lumini, Andrea, and Eugenia Bordini. 2019. Le robbiane al Santuario della Verna: Sperimentazioni di rilievo digitale e modellazione 3D. Reflections: The Art of Drawing/the Drawing of Art. Paper presented at 41st Convegno Internazionale dei Docenti delle Discipline della Rappresentazione, Perugia, Italy, September 19-21; pp. 16-23.

Marquand, Allan. 1919. Robbia Herladry. Princeton: Princeton University Press.

Marquand, Allan. 1922. Andrea della Robbia and His Atelier. Princeton: Princeton University Press, vol. I-II. 
Mencherini, P. Saturnino. 1924. Codice Diplomatico della Verna e delle SS. Stimate di S. Francesco d'Assisi nel VII Centenario del Gran Prodigio. Florence: Tipografia Gualandi.

Miller, Stephanie R. 2003. Andrea della Robbia and His La Verna Altarpieces: Context and Interpretation. Ph.D. dissertation, Indiana University, Bloomington, IN, USA.

Miller, Stephanie R. 2010. The Chapel of the Stigmata at the Franciscan Monastery of La Verna. In The Chapels of Italy from the Twelfth to the Eighteenth Centuries: Art, Religion, Patronage, and Identity. Edited by Lilian H. Zirpolo. Woodcliff Lake: WAPACC Organization, pp. 155-76.

Miller, Stephanie R. 2013. A material distinction: Fifteenth-century tin-glazed terracotta portraits in Italy. Sculpture Journal 1: 7-20. [CrossRef]

Moorman, John. 1988. A History of the Franciscan Order from Its Origins to the Year 1517. Chicago: Franciscan Herald Press.

Moroni, Lino. 1999. Descrizione del Sacro Monte Della Vernia. Florence: Polistampa.

Muzzi, Andrea. 1998. Gli osservanti francescani, i savanorolani e Andrea della Robbia. In I della Robbia e l'arte Nuova' Della Scultura Invetriata. Edited by Giancarlo Gentilini. Florence: Giunti, pp. 43-56.

Muzzi, Andrea. 2000. Temi religiosi nella decorazione di Andrea della Robbia per la Chiesa Maggiore della Verna: Appunti sul Metodo di Studio. Studi Francescani 3-4: 511-21.

Paloscia, Tommaso, and Fabio Bernacchi, eds. 1986. Le Robbiane Della Verna. Chiusi della Verna: La Verna.

Panzanelli, Roberta, ed. 2008. The Color of Life: Polychromy in Sculpture from Antiquity to the Present. Exh. Cat. Los Angeles: Getty Publications.

Pastor, Ludwig. 1969. History of the Popes from the Close of the Middle Ages, reprint, 6th ed. London and St. Louis: Routledge, vol. I, pp. 1938-61, reprint, Nendeln: Kraus Reprint.

Pope-Hennessy, John. 1979. Thoughts on Andrea della Robbia. Apollo 205: 176-97.

Quiviger, François. 2010. The Sensory World of Italian Renaissance Art. London: Reaktion Books Ltd.

Rarick, Holly. 1990. Pinturicchio's Saint Bernardino of Siena Frescoes in the Bufalini Chapel, S. Maria in Aracoeli, Rome: An Observant Franciscan Commentary of the Late 15th Century. Ph.D. dissertation, Case Western University Ohio, Cleveland, OH, USA.

Reinburg, Virginia. 2012. French Books of Hours: Making an Archive of Prayer, c. 1400-1600. Cambridge: Cambridge University Press.

Richardson, Jessica N. 2019. Visible Parlare: Inscribed Prayers, Apotropaic Aphorisms and Monumental Mobile Images in FourteenthCentury Bologna. In Sacred Scripture/Sacred Space: The Interlacing of Real Places and Conceptual Spaces in Medieval Art and Architecture. Edited by Tobias Frese, Wilfried E. Keil and Kristina Krüger. Berlin: De Gruyter, pp. 351-86.

Ritsema van Eck, Marianne Petra. 2017. Custodians of Sacred Space Constructing the Franciscan Holy Land through Texts and Sacri Monti. (ca. 1480-1650). Amsterdam: University of Amsterdam.

Ruda, Jeffrey. 1993. Fra Filippo Lippi: Life and Work. London: Phaidon Press.

Salmi, Mario. 1969. Fortuna di Andrea della Robbia. Commentari 20: 270-80.

Sarnecka, Zuzanna. 2019. 'And the Word Dwelt amongst Us': Experiencing the Nativity in the Italian Renaissance Home. In Domestic Devotions in Early Modern Italy. Edited by Corry Maya, Faini Marco and Meneghin Alessia. Leiden and Boston: Brill, pp. 163-84.

Sarnecka, Zuzanna. 2020. Experiencing La Verna at Home: Italian Sixteenth-Century Maiolica Sanctuaries and Chapels. Religions 6: 6. [CrossRef]

Shearman, John. 1992. Only Connect: Art and the Spectator in the Italian Renaissance. Princeton: Princeton University Press.

St. Bernardino of Siena. 1935. Secondo Quaresimale di Firenze (1425): Le Tre Qualità del Cavallo e dell'Anima Giusta. In Le prediche Volgari inedite. Siena: E. Cantagalli.

Tanzini, Lorenzo. 2012. La Verna e I poteri pubblici cittadini. In Altro Monte non ha più santo il mondo. Storia, architettura ed arte alla Verna dalle origini al primo Quattrocento. Edited by Nicoletta Baldini. Chiusi della Verna: Atti del Convegno di studi, Convento della Verna, pp. 221-40.

Tarr, Roger. 1997. 'Visible Parlare': The spoken word in fourteenth-century central Italian painting. Word and Image 3: 223-44.

Terry-Fritsch, Allie. 2020. Somaesthetic Experience and the Viewer in Medicean Florence: Renaissance Art and Political Persuasion, 1459-1580. Amsterdam: Amsterdam University Press.

Thurston, Herbert. 1901. Popular Devotions: The Angelus. The Month 97: 483-99.

Thurston, Herbert. 1907. Angelus. In The Catholic Encyclopedia. New York: Robert Appleton Company.

Tripodi, Claudia. 2014. I rapporti di Firenze con il convento della Verna visti attraverso la famiglia committente dei Della Robbia. In Altro Monte non ha più santo il mondo. Storia, architettura ed arte alla Verna fra il XV ed il XVI secolo. Edited by Nicoletta Baldini. Chiusi della Verna: Atti del Convegno di studi, Convento della Verna.

Van Dijk, Ann. 1999. The Angelic Salutation in Early Byzantine and Medieval Annunciation Imagery. Art Bulletin 3: 420-36. [CrossRef] Wallis, Mieczyslaw. 1973. Inscriptions in Paintings. Semiotica 9: 1-28. [CrossRef]

Williamson, Beth. 2004. Altarpieces, Liturgy, and Devotion. Speculum 2: 341-406. [CrossRef] 